\title{
MATHEMATICAL REASONING AND SELF REGULATED LEARNING ACCORDING TO STUDENT'S COGNITIVE STAGE
}

\author{
Gunawan $^{1}$, Ambar Prawoto ${ }^{2}$, Utari Sumarmo ${ }^{3}$ \\ 1,2,3 Mathematics Education Program Post Graduate IKIP Siliwangi, Cimahi \\ 'gunawantujuh7@gmail.com, ${ }^{2}$ ambarprawoto34@gmail.com, ${ }^{3}$ utari.sumarmo@gmail.com
}

Received: Jul 6 ${ }^{\text {th }}$, 2019; Accepted: Jul 17 $7^{\text {th }}, 2019$

\begin{abstract}
This study was a descriptive survey having a goal to examine attainment of student's mathematical reasoning (MR) and self regulated learning(SRL) according to student's cognitive stage. The survey implicate 36 eleventh grade students, test of logical thinking (TOLT), an essay MR test,a SRL scale. By using TOLT, the survey investigated many students with 17 years old had not reached formal cognitive stage, namely $19 \%$ students at formal stage, $25 \%$ students at transition stage, and rest 56\% students at concrete stage. Survey invented that entirely students obtained MR at very low grade level, and according to student's cognitive stage, formal students obtained higher grade MR than the grade of transisiton students and concrete students. Other finding, there was medium association between cognitive stage and MR, but therewere no association between cognitive stage and MR, and SRL and between MR and SRL. In general, these findings were, that in normal condition formal cgnitive stage will reach by students in $12-13$ years old, or in 13-14 years old, even in specific condition in $19-20$ years old; and that formal students possess higher abilities than concrete students on completing HOT tasks such as MR tasks which needed formal operational thinking.
\end{abstract}

Keywords: cognitive stage, TOLT, mathematical reasoning, self regulated learning

\begin{abstract}
Abstrak
Penelitian ini adalah survei deskriptif yang memiliki tujuan untuk menguji pencapaian penalaran matematis (MR) siswa dan kemandirian belajar (SRL) sesuai dengan tahap kognitif siswa. Survei ini melibatkan 36 siswa kelas sebelas, tes berpikir logis (TOLT), tes MR esai, skala SRL. Dengan menggunakan TOLT, survei menyelidiki banyak siswa dengan 17 tahun belum mencapai tahap kognitif formal, yaitu 19\% siswa pada tahap formal, 25\% siswa pada tahap transisi, dan sisanya 56\% siswa pada tahap konkret. Survei menemukan bahwa seluruh siswa memperoleh MR pada tingkat kelas yang sangat rendah, dan menurut tahap kognitif siswa, siswa formal memperoleh MR kelas lebih tinggi daripada siswa transisiton dan siswa beton. Temuan lainnya, ada hubungan sedang antara tahap kognitif dan MR, tetapi tidak ada hubungan antara tahap kognitif dan MR, dan SRL dan antara MR dan SRL. Secara umum, temuan ini adalah, bahwa dalam kondisi normal tahap kognitif formal akan dicapai oleh siswa di 12 -13 tahun, atau di 13-14 tahun, bahkan dalam kondisi khusus di 19-20 tahun; dan bahwa siswa formal memiliki kemampuan yang lebih tinggi daripada siswa konkret dalam menyelesaikan tugas-tugas PANAS seperti tugas MR yang memerlukan pemikiran operasional formal.
\end{abstract}

Kata kunci: Tahap Kognitif, TOLT, Penalaran Matematik, Kemandirian Belajar

How to Cite: Gunawan, Prawoto, A., \& Sumarmo, U. (2019). Mathematical Reasoning and Self Regulated Learning According to Student's Cognitive Stage. JIML, 2 (1), 39-52. 


\section{INTRODUCTION}

To examine student's cognitive stage, our discourse will relate tightly to the well-known theory that was Piaget's theory (Sumarmo, 1987) of cognitive child development. IN the begining, some readers believed that student's cognitive development is determined by biological age, such as by knowing student's age a reader we know student's cognitive stage directly. This opinion was serious inaccuracy. Basically, Inhelder and Piaget (Sumarmo, 1987) by using concsentious observation and in depth interview, they idenfied student's reasoning ablities on various reasoning tasks. Then they classified kinds of reasoning which able and not able to do by each groups of children from infant up to adult. Based on student's ways of reasoning, then Inhelder and Piaget (Sumarmo, 1987) then categorized them into five main cognitive stages, namely: sensory-motor operasional stage (infant-2 years old), preconcrete operational stage ( 2 - 7 year old), concrete operasional stage ( 7 - 12 years old), and formal operational stage stage (13-14 years old or 14-15 years old).

To avoid time comsumning in implementation of accurate observations and interviews, Capie and Tobin (Sumarmo, 1987) compiled a written test to substitute Inhelder and Piaget's technique for determining student's cognitive stage for number of students in shorter time and all at once together. The test was konwn as test of logical thinking (TOLT) and it constituted of ten items measuring controlling variable reasoning, proportional reasoning, probability reasoning, and combinatorial reasoning. In order to obtain valid instrument of the TOLT, then Capie and Tobin (Sumarmo, 1987) carried out cross-cultural studies on TOLT with a number of student from eighth grade up to tertiary (college) students. The cross-cultural studies found that many students of more than 15 years old had not reached formal operational stage yet, but in higher student's grade school there found greater percentage of formal students' and lower percentage of concrete students. In addition, the cross cultural studies also invented that in higher school grade study found greater percentage of formal students and smaller percentage concrete students. In principle, those findings supported statement that TOLT was a valid written test for measuring cognitive operational stage of students according to Piaget's theory.

Discussion on logical reasoning our discussion closed to mathematical reasoning term. Teachers aware that mathematical reasoning (MR) is one of essential mathematics ability should be mastered by high school students. The last statement not only caused of MR is enclosed in the goal of mathematics teaching (National Council of Teachers of Mathematics, 2000; Permendikbud, 2013) but it was agreeable to some mathematics experts' opinion as well. The goal of teaching mathematics, among other things were: to develop student's potency to become a critical, creative, logical, accurate, and innovative human. (Permendikbud, 2013).

There are some experts' notion about MR namely: a. MR is to derive conclussion based on proper data, event, facts, evidence, and or sources (Hendriana, Rohaeti, \& Sumarmo, 2014; Kusnandi \& Sumarmo, 2010); b.MR is to think logically about and with mathematicsobject (Kusnandi \& Sumarmo, 2010). When we pay deep attention on mathematical processes 
42 Gunawan, Prawoto, \& Sumarmo, Mathematical Reasoning and Self Regulated Learning According to Student's Cognitive Stage

involved in MR, it portraits that MR was higher order thinking (HOT) in mathematics. It implied in solving MR beside students should master mathematics content, they also should own certain disposition as well, such as having self confidence, habit to work hard and to monitor his learning, ability to manage his learning. Such kind of mathematical disposition was self regulated learning (SRL). Some experts (Butler, 2002; Kerlin, 1992; L. \& Randi, 1999; Paris \& Winograd, 1998; Schunck \& Zimmerman, 1998; Sumarmo, 2006), defined SRL in different expressions, but they containsome similar components, namely: to plan self learning objective; to select strategy; and to monitor, to evaluate learning processes and to compare them to a certain standard. Self regulated learning will require them to be active both before and after the learning process takes place, so that students who apply independent learning will be able to solve their own problems (Amalia, Syafitri, Sari, \& Rohaeti, 2018).

In addition, some studies (Aminah, Kusumah, Suryadi, \& Sumarmo, 2017; Bernard \& Rohaeti, E, 2016; Maya \& Sumarmo, 2014; Qohar \& Sumarmo, 2014) by implementiing various teaching approaches invented that students obtained MR at low to medium grade level. Likewise, other studies (Damayanti, Sumarmo, \& Maya, 2018; Qohar \& Sumarmo, 2014; Sumarni \& Sumarmo, 2017) detected that students attained SRL at fairly good grade level.

Those afformentioned arguments stimulated researchers to excecute a study to analyze role of cognitive stage on obtaining student's MR, SRL and then we compile research questions as follows.

a. What are student's percentage on each cognitive stage measured by using TOLT?

b. What are student's grade on MR and on SRL for entirely students and according to its cognitive stage?

c. What kind of student's difficulties on solving MR tasks?

d. Is there any association between cognitive stage and MR, between cognitive stage and SRL, and between MR and SRL and SRL.

\subsection{Theoretical Review}

\section{Stage of Child's Cognitive Development}

To analize the way of children reasoning, Inhelder and Piaget (Sumarmo, 1987) executed a series of accurate observations through experiment and individual interviews toward a number of subjects of various age groups from children up to adult from various best of schools in Geneva. Based on those observations and interviews then Inhelder and Piaget (Sumarmo, 1987) identified cognitive abilities which able to do or not able to do by each age group of children. By analyzing the structure of each age group of children, then Inhelder and Piaget (Sumarmo, 1987) classified subjects into four main stages of thinking or stage of child cognitive development, namely: a) Sensory-motor stage (infant up to 2 years old); b) Preconcrete operational stage ( $2-7$ years old); c) Concrete operational stage (7-12 years old); d) formal operational stage (13-14 years old or 14-15 years old).

To overcome time consuming for implementing depth observation and interview for a number of students in shorter time at once, Tobin and Capie (Sumarmo, 1987) developed a written tes 
called test of logical thinking (TOLT) which compiled based on theory of Inhelder and Piaget child cognitive develpoment. The TOLT was in multiple choice form of five option accompanied with 5 choices of reason. The tests measured four reasoning abilities those were: controlling variables, proportional reasoning, probabilistics reasoning, corelational reasoning, and combinatorial reasoning. Capie and Tobin (Sumarmo, 1987) with a number of subjects from primary school up to college students, reported their findings as in Table 1. Those findings pointed out that the TOLT was group test that measured formal thinking ability for a number of students of various age and cultures in shorter time at once.

Table 1. Findings in Validation Studies on TOLT of Tobin dan Capie

\begin{tabular}{lcccc}
\hline \multicolumn{1}{c}{ Subject } & $\mathbf{N}$ & $\begin{array}{c}\text { \% Concrete } \\
\text { Stage }\end{array}$ & $\begin{array}{c}\text { \% Transition } \\
\text { Stage }\end{array}$ & $\begin{array}{c}\text { \% Formal } \\
\text { Stage }\end{array}$ \\
\hline $6^{\text {th }}$ grade student & 100 & 97 & 3 & 0 \\
$7^{\text {th }}$ grade student & 86 & 96 & 2 & 2 \\
$8^{\text {th }}$ grade student & 167 & 86 & 9 & 5 \\
$11^{\text {th }}$ grade student & 82 & 32 & 17 & 51 \\
College student & 247 & 45 & 18 & 37 \\
\hline
\end{tabular}

Source: Tobin and Capie 1981 (Sumarmo, 1987)

Those studies studies found many subjects of more than 15 years old had not attained formal operational stage yet. However, studies also found in higher school grade there were greater percentage formal subjects and smaller percentage concrete students. Those findings were fitting to further hypothesis of Inhelder and Piaget that normal subject will reach formal operational stage in between 11-12 years old up to 14 - 15 years old, even in other condition in $18-20$ years old.

\subsection{Mathematical Reasoning Ability and Self Regulated Learning}

Based on some experts' conception (Aminah et al., 2017), Classified MR into two kinds those are inductive and deductive mathematical reasoning (Sumarmo, 2006). Then, inductive MR was to derive conclussion based on observed data or process. Further, she detailed inductive MR into some kinds of activities, namely: a. transductive reasoning; b. Analogycal reasoning; c. Generalization; d. Predicting solution or tendency; e. Giving explanation based on model, facts, attributes, relation or pattern; and f. Applying relationship of pattern for analyzing situation, and compiling conjecture (Sumarmo, 2006).

While deductive MR was to attract conclussion based on proper rules. Deductive MR involed some activities: a.To carry out calculation agreed to proper rules and principles; b.To reason based on the rules of inference (proposisional reasoning); To examine validity of an argument, to prove and to compile valid argument; c.To reason based on ratio between two or more components (proportional reasoning) (Aminah et al., 2017); d. To conclude based on combination of some elements (combinatorial reasoning) (Aminah et al., 2017); e.To conclude based on probability of an event (probabilistic reasoning); f. To correlate relationships between two different situations (Aminah et al., 2017); g. To proof the truth of statement directly, indirectly, or proving by mathematics induction. 
44 Gunawan, Prawoto, \& Sumarmo, Mathematical Reasoning and Self Regulated Learning According to Student's Cognitive Stage

When we paid deep attention to those processes involved on MR, we get impression there were various level of thinking of those processess from medium to very high level. Therefore, we have to determine definite indicators fitting for certain school level of students. For examples, for yunior high school students, we restrict indicators of MR on transductive, analogical, generalization and proportional reasoning, predicting, and executing enumeration based on certain rules and principles. Whereas, for senior high school or university studentsallmost indicators of mathematical reasoning able to beassessed to them provided they are relevant to the learned mathematics contents.

Based on indicators of MR we infered that MR was HOT mathematics tasks which it needed strong mathematics disposition in solving MR tasks. That disposition involved high motivation, habit to work hard, and ability to organize self-learning. That kind of disposition was self regulated learning (SRL). Some writers defined SRL in various expression as follow: a. SRL is was to design and to observe self learning process carefully in completing academic task (Kerlin, 1992); b. SRL was ability to observe self behaviour and as hard work human personality (Kerlin, 1992). Further he elaborates activities of SRL more detailed, such as: to assess own-self, to determine learning goal and conception; to collect,to notation; c. SRL is learning process affected by thinking, feeling, strategy, and own behaviour oriented to the realizing goal. SRL involves three phases namely: to design andto observe learning activities, and to assess and to reflect learning out comes (Schunck \& Zimmerman, 1998); SRL was cycle of recursive cognitive activities that holds to analyze task, to choose, to adopt, or to invent strategy for obtaining the goal of task, and to monitor learning out comes; $d$. Other term of SRL namely self-direction on learning(SDL) is responsible individual learning process in planning, excecuting, and assessing his learning (Wongsri, Cantwell, \& Archer, 2002); e. Hoban, Sersland, Raine (Wongsri et al., 2002) name SDL as self efficacy that is individul view point toward his own abilities.

Some indicators of SRL as follow:a.Awareness toward learning goal so that learning becomes more directed, concentrated, and keep going for long time; b. Awareness toward learning responsible; c. Learning continuously so that it composes ordered learning habits; d. Learning actively through reading various sources, and relating prior and new knowlegde, working in a group actively and creatively and posing question actively toward unclear matters; e. Learning efficiently by arranging time fitting to depth and wideness of learning material (Djamarah \& Zain, 2002; Paris \& Winograd, 1998)

Some writers offer some suggestion to enchance student's SRL, among other as follow: a. SRL ables to improve by any relevant teachinh approach (Sumarmo, 2006; Wongsri et al., 2002); b. Teacher ought to assisst student to carry out SRL cycles flexibly and as creatively through: analyzing task, sellecting and implementing strategy, self monitoring and reflecting (Butler, 2002; Sumarmo, 2006); c. Other some suggestion for developing SRL are: Create conducive learning environment, remember student tofollow certain guideliness, Motivate student to comprehend the true procedure in solving task, assist student to manage time, promote student's self confidence that he able to complete the task, stimulate student to 
control his emotion and not easy be panic, show student's success and assist student to look for learning help.

Other writers (Zumbrunn, Tadlock, \& Robert, 2011) pose some strategy for forming SRL as follow: a. Settingshort and long term goal; b.Planningself managing; c. Promoting own self motivation; d. Developing own attention control; e. Excecuting flexible strategy; f) Carrying out self monitoring; g. Trying help seeking; h.Performimg self evaluation.

Further, based on writers' conception (Butler, 2002; L. \& Randi, 1999; Paris \& Winograd, 1998; Schunck \& Zimmerman, 1998; Sumarmo, 2006; Wongsri et al., 2002). Indicators of SRL as follow: a. To have intrinsic learning initiative and motivation; $b$. To own habits to diagnose learning needs $\mathrm{c}$. To determine learning target; $\mathrm{d}$ To monitor, to manage, and to control self learning; e. to To regard difficulty as challenge; f. To use and to seek relevant sources; g. To sellect and to carry out strategy; h. To assess learning process and out comes; i. To perform self efficacy (Sumarmo, 2006)

\subsection{Relevant Studies}

Beside afformentioned studies' findings,since long ago, there were some studies reported supperiorities of formal stage subjects than concrete stage subjects on various mathematics abilities. For examples: McDonald (Sumarmo, 1987) on structure of geometry of tenth grade students, and Lawson \& Lawson (Sumarmo, 1987) on composing argument and testing hypothesis of college students.

In order to use written test for determining student's cognitive stage on Indonesia students, Translated TOLT into Indonesian culture and validated the test to original TOLT (Sumarmo, 1987). Further, by implementing translated TOLT and Longeot test carried out precise survey with 414 eleventh grade students of 17,43 years old from some Senior High School in seven cities in West of Java. The survey invented that $48 \%$ students had reached formal stage, $22 \%$ students at transition stage, and $30 \%$ students still at concrete stage. In addition, the survey reported superiority of formal stage than transition stage, and the excellence of transitional stage than concrete stage students on mathematical understanding and reasoning. Likewise. Those findings were fitting to Piaget's theory that formal stage students were smarter than concrete stage students in solving HOT mathematics tasks which required formal process of thinking (Sumarmo, 1987)

Moreover, other some recent studies (Koswara, Sumarmo, \& Kusumah, 2012; Kusnandi \& Sumarmo, 2010; Offirston \& and Sumarmo, 2012; Rijaya, Sumarmo, \& Syaban, 2018; Setiawati, 2014; Sumarni \& Sumarmo, 2017) by using various teaching approaches detected that students obtained MR at medium to fairly good grade level.Similarly,other studies (Mulyana \& Hendriana, 2015; Retnaningsih \& Sugandi, 2018; Rohaeti, Budiyanto, \& Sumarmo, 2014; Setiawati, 2014) found that students attained SRL at fairly good grade level. Seemingly, for high school students to solve MR tasks were more difficult than to perform SRL attitudes.

\section{METHOD}


This study is a descriptive survey having a goal to explore relation of student's cognitive stageon attainment of MR and SRL. Thesurvey involved 36 eleventh grade students of a school determined purposively,TOLT of Cpaie and Tobin (Sumarmo, 1987), an essay MR test and a SRL scale developed special for this survey. The MR test consists of 5 items, and by using a guide it was obtained charactristic of MR test and SRL scale were attached in Table 2 (Hendriana \& Sumarmo, 2014). Data analysis of this survey involved: computation for items scoring for SRL scale, percentage comptutaion, $t$ testing hypothesis of mean difference, $\chi^{2}$ for testing of existance of association of two variables, and other rational analysis for relevant data.

Table 2. Characteristics of Instruments of This Study

\begin{tabular}{ccccccc}
\hline $\begin{array}{c}\text { Test and } \\
\text { Scale }\end{array}$ & $\begin{array}{c}\mathbf{N} \\
\text { Subyect }\end{array}$ & $\begin{array}{c}\text { n Item } \\
\text { Test \& } \\
\text { Scale }\end{array}$ & $\begin{array}{c}\text { Discriminat } \\
\text { power }\end{array}$ & $\begin{array}{c}\text { difficulty } \\
\text { index }\end{array}$ & $\begin{array}{c}\text { Item } \\
\text { validity }\end{array}$ & Reliability \\
\hline TOLT* $^{*}$ & 92 & 10 & $.42-.84$ & $.37-.83$ & $.59-.81$ & .66 \\
MR** $^{*}$ & 36 & 5 & $.15-.50$ & $.12-.53$ & $.23-.67$ & .83 \\
SRL** & 36 & 30 & $.00-.53$ & $.63-.88$ & $1.87-4.44$ & .77 \\
\hline
\end{tabular}

Note: * adopted from McDonald (Sumarmo, 1987)

**analyzed in Gunawan et.all., 2019

2.1. In the following we attached some sample of instruments of this study.

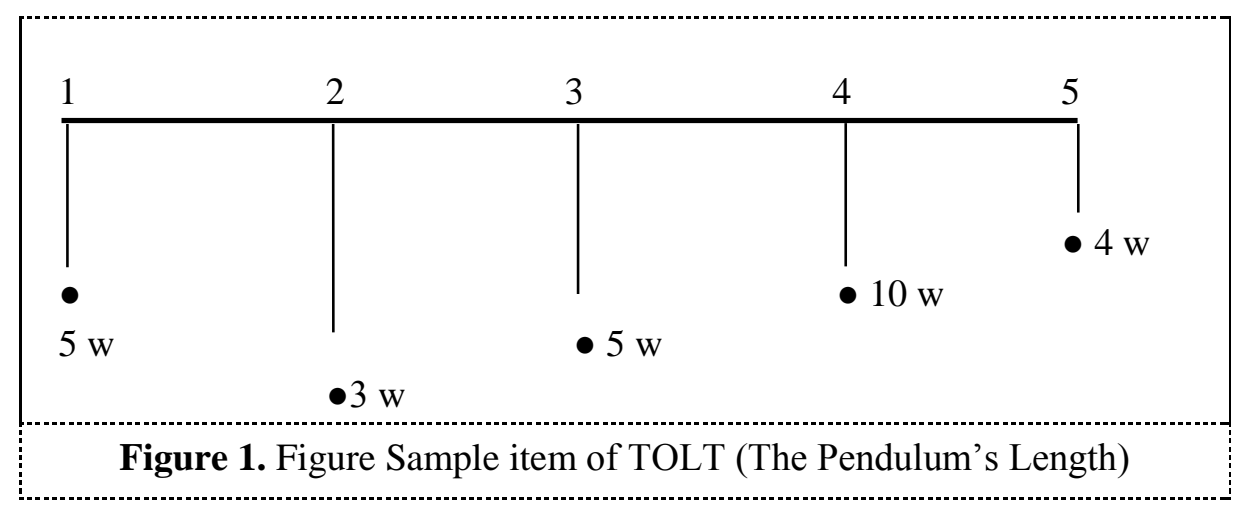

Suppose you wanted to do an experiment to find out if changing the length of a pendulum changed the amount of time it takes to swing back and forth. Which of the pendulum would you use for the experiment?
a. 1 and 4
d. 2 and 5
b. 2 and 4
e. All
c. 1 and 3

Reasons:

1. The longest pendulum should be tested against the shortest pendulum.

2. All pendulum need to be tested against one another.

3. As the length is increased the number of washers should be decreased. 
4. The pendulum should be the same length but the number of washers sould be different.

5. The pendulums should be different lengths but the number of washers should be the same.

\subsection{Sample Item of Mathematical Reasoning (MR): analogical reasoning}

It is given a square of its side is 10 unit. Through midle point of each side, draw a second square. Observe a triangle inside of first square and out side of second square. Name the area of the first triangle is $\mathrm{L}_{1}$. Through midle point of each side of the second square, then draw the third square and observe a triangle inside of second square and out side of third square. Name the area of the second triangle is $\mathrm{L}_{2}$. Those processess is continued up to fifth triangle.

a. Draw that situation and indentified each triangle and its area.

b. Determine sum of area of first triangle up to fifth triangle and explain concepts and rule used in each step of solving it.

\subsection{Sample items of Self Regulated Learning (SRL) Scale}

Table 3. Sample items of Self Regulated Learning

\begin{tabular}{|l|l|l|l|l|l|}
\hline No. & Activity, feeling, or opinion & QO & O & S & QS \\
\hline 1. & $\begin{array}{l}\text { Select difficult mathematics task about general form of } \\
\text { pattern } P_{n} \text { caused of liking to do it. }\end{array}$ & & & & \\
\hline 2. & $\begin{array}{l}\text { Try to identify self weakness in learning aritmetics and } \\
\text { geometry sequence and series }\end{array}$ & & & \\
\hline 3. & $\begin{array}{l}\text { To learn arithmetics sequence and series without target } \\
\text { will lighten learning task. }\end{array}$ & & & \\
\hline
\end{tabular}

Note: QO quiet often ; O: often; S: seldom; QS: quiet seldom

\section{RESULTS AND DISCUSSION}

Description of MR, and SRL in entirely and grounded on student'scognitive stage were attached in Table 2.

Table 4. Description of Student's Mathematical Reasoning and Student's Self Regulateg Learning Grounded on Student's Cognitive Stage

\begin{tabular}{cccccccccc}
\hline Variable & Statists & $\begin{array}{c}\text { Concrete } \\
\text { Stage }\end{array}$ & $\begin{array}{c}\mathbf{N} \\
(\boldsymbol{\%})\end{array}$ & $\begin{array}{c}\text { Transitio } \\
\mathbf{n}\end{array}$ & $\begin{array}{c}\mathbf{n} \\
\mathbf{( \% )}\end{array}$ & $\begin{array}{c}\text { Formal } \\
\text { Stage }\end{array}$ & $\begin{array}{c}\mathbf{n} \\
(\boldsymbol{\%})\end{array}$ & Total & $\mathbf{n}$ \\
\hline \multirow{2}{*}{ MR } & $\bar{x}$ & 10.40 & 20 & 23.57 & 7 & 36.33 & 9 & 19.44 & 36 \\
$(\mathrm{IS}=69)$ & $\% \mathrm{IS}$ & $15.07 \%$ & $56 \%$ & $34.16 \%$ & $19 \%$ & $52.66 \%$ & $25 \%$ & $28.18 \%$ & 100 \\
& $\mathrm{~S}$ & 7.39 & & 4.31 & & 10.52 & & 13.48 & $\%$ \\
SRL & $\bar{x}$ & 93.35 & & 93.86 & & 94.00 & 9 & 93.61 & 36 \\
$(\mathrm{IS}=120)$ & $\% \mathrm{IS}$ & $77.79 \%$ & 20 & $78.21 \%$ & 7 & $78.33 \%$ & $25 \%$ & $78.01 \%$ & 100 \\
& $\mathrm{~S}$ & 7.94 & & 7.31 & & 11.90 & & 8.71 & $\%$ \\
\hline
\end{tabular}


42 Gunawan, Prawoto, \& Sumarmo, Mathematical Reasoning and Self Regulated Learning According to Student's Cognitive Stage

From Table 4, for entirely students and transition and concrte students survey found MR at very low grade level, and formal students attained MR at low grade level. This findings were different with findings of previous studies (Bernard \& Rohaeti, E, 2016; Mulyana \& Hendriana, 2015; Prasetio, Sumarmo, \& Sugandi, 2018; Sumarni \& Sumarmo, 2017) that students getting treatment with various innovative teaching attained MR at medium grades. But that findings were similar to findings of other studies (Aminah et al., 2017; Dasari \& Sumarmo, 2010; Kusnandi \& Sumarmo, 2010; Maya \& Sumarmo, 2014; Rohaeti et al., 2014; Setiawati, 2014; Sumarmo, Hidayat, Zulkarnaen, \& Hamidah, Sariningsih, 2012) that students obtained at low grade level. Seemingly, innovative teaching mathematics gave different result on students' grades of MR from low level up to good level. The low students' grades on MR were found on studies with senior high school students and on intermediate mathematics course such as system of equation of two and more variables, (Aminah et al., 2017; Setiawati, 2014) and on proving problems (Dasari \& Sumarmo, 2010; Kusnandi \& Sumarmo, 2010; Maya \& Sumarmo, 2014). Testing hypothesis on mean difference on MR of each student's stage were attached on Table 3.

Table 5. Testing Hypotesis of Mean Difference of Mathematical Reasoning and Self Regulated Learning according to Student's Cognitive Stage

\begin{tabular}{ccccccc}
\hline \multirow{2}{*}{ Variable } & $\begin{array}{c}\text { Cognitive } \\
\text { Stage }\end{array}$ & $\overline{\boldsymbol{x}}$ & $\mathbf{S}$ & $\mathbf{N}$ & Sig (1-tailed). & Interpretation \\
\hline \multirow{3}{*}{ MR } & Formal & 36.33 & 10.52 & 9 & $.010<.05$ & MR $_{\mathrm{F}}>\mathrm{MR}_{\mathrm{T}}$ \\
& Transition & 23.57 & 4.31 & 7 & & \\
& Transition & 23.57 & 4.31 & 7 & $0.00<.05$ & MR $_{\mathrm{T}}>\mathrm{MR}_{\mathrm{C}}$ \\
& Concrete & 10.40 & 7.39 & 20 & & No different SRL $_{\mathrm{F}}$ and \\
\multirow{5}{*}{ SRL } & Formal & 94.00 & 11.90 & 9 & $.978>.05$ & SRL $_{\mathrm{T}}$ \\
& Transition & 93.86 & 7.31 & 7 & & ${\text { No different } \mathrm{SR}_{\mathrm{T}} \text { and }}$ \\
& Transition & 93.86 & 7.31 & 7 & $.883>.05$ & SRL $_{\mathrm{C}}$ \\
\hline
\end{tabular}

Note: MR: mathematical reasoning SRL: self regulated learning Ideal score MR: 69 Ideal scoreSRL: 120

Further analysis was concerned with student's difficulties on solving MR tasks. The data were illustrated in Table 5. The survey found that, all students (concrete, transition, and formal stage) realized difficulties in all items test of MR. These findings were similar to findings on other previous studies (Aminah et al., 2017; Bernard \& Rohaeti, E, 2016; Koswara et al., 2012; Mulyana \& Hendriana, 2015; Rohaeti et al., 2014; Setiawati, 2014; Sumarni \& Sumarmo, 2017) that many students experienced many difficulties on accomplishing MR tasks.

Table 6. Mean Score of Each Item of Mathematical Reasoning According to Student's Cognitive Stage

\begin{tabular}{ccccccc}
\hline $\begin{array}{c}\text { Cognitive } \\
\text { Stage }\end{array}$ & $\begin{array}{c}\text { Item } \\
\text { number. } \\
\text { Ideal score }\end{array}$ & $\mathbf{1 2}$ & $\mathbf{1 5}$ & $\mathbf{1 5}$ & $\mathbf{1 5}$ & $\mathbf{1 2}$ \\
\hline Formal & $\bar{x}$ & 6.67 & 8.22 & 10.00 & 5,00 & 2.12 \\
\hline
\end{tabular}




\begin{tabular}{ccccccc}
\hline \multirow{3}{*}{ Transition } & $\%$ of IS & $55.58 \%$ & $54.80 \%$ & $66.67 \%$ & $33.33 \%$ & $3.07 \%$ \\
& $\bar{x}$ & 4.86 & 7.57 & 5.57 & 3.00 & 2.57 \\
& $\%$ of IS & $40.05 \%$ & $50.47 \%$ & $37.13 \%$ & $20.00 \%$ & $21.42 \%$ \\
Concrete & $\bar{x}$ & 3.20 & .85 & 2.20 & 1.35 & 2.80 \\
& $\%$ of IS & $26.67 \%$ & $5.67 \%$ & $14.67 \%$ & $9 \%$ & $23.33 \%$ \\
\hline
\end{tabular}

Mathematical Reasoning

Ideal score MR: 69

Afterward analysis were contigency computation between cognitive stage and MR, between cognitive stage and SRL, and between MR and SRL. By using contigency table and statistic Pearson-Chi Square $\left(\chi^{2}\right)$ the survey found contigency of those variables such as in Table 5, Table 7, and Table 8, and their hypothesis testing were in Table 9.

Table 7. Contigency Table of Cognitive Stage (CS) and Mathematical Reasoning (MR)

\begin{tabular}{ccccc}
\hline CS & $\begin{array}{c}\text { Formal } \\
\text { Stage }\end{array}$ & $\begin{array}{c}\text { Trans. } \\
\text { Stage }\end{array}$ & $\begin{array}{c}\text { Concr. } \\
\text { Stage }\end{array}$ & Total \\
\hline High & 7 & 1 & 0 & 8 \\
Medium & 2 & 6 & 11 & 19 \\
Low & 0 & 0 & 9 & 9 \\
Total & 9 & 7 & 20 & 36 \\
\hline
\end{tabular}

Table 8. Contigency Between Cognitive Stage (CS) Table 9. Contigency Between MR and Self Regulated Learning (SRL) and SRL

\begin{tabular}{cccccccccc}
\hline CS & $\begin{array}{c}\text { Formal } \\
\text { Stage }\end{array}$ & $\begin{array}{c}\text { Trans. } \\
\text { Stage }\end{array}$ & $\begin{array}{c}\text { Concr. } \\
\text { Stage }\end{array}$ & Total & MR & High & Medium & Low & Total \\
\hline High & 3 & 1 & 5 & 9 & High & 3 & 3 & 2 & 8 \\
Medium & 3 & 4 & 10 & 17 & Medium & 4 & 9 & 6 & 19 \\
Low & 3 & 2 & 5 & 10 & Low & 2 & 5 & 2 & 9 \\
Total & 9 & 7 & 20 & 36 & Total & 9 & 17 & 10 & 36 \\
\hline
\end{tabular}

According to findings on Table 7, Table 8, Table 9, and Table 10 survey invented there was high association between student's CS and MR, even if there were no association between student's CS and SRL and between MR and SRL. Those findings were understandable caused of both CS and MR tasks measured similar cognitive abilities namely reasoning tasks. While CS and SRL, and MR and SRL measured different abilities such as cognitive and affective variables.

Table 10. Test of Pearson-Chi Square and Contigency Coefficient between Cognitive Stage, Mathematical Reasoning and Self Regulated Learning

\begin{tabular}{|c|c|c|c|c|c|}
\hline $\begin{array}{c}\text { Association } \\
\text { Between } \\
\text { Variable }\end{array}$ & $\begin{array}{c}\text { Pearson- } \\
\text { Chi Square } \\
\left(\chi^{2}\right)\end{array}$ & DF & $\begin{array}{l}\text { Contigency } \\
\text { Cofficient } \\
\text { (C) }\end{array}$ & $\begin{array}{c}\text { Sig. } \\
\text { (2-tailed) }\end{array}$ & Interpretation \\
\hline
\end{tabular}


44 Gunawan, Prawoto, \& Sumarmo, Mathematical Reasoning and Self Regulated Learning According to Student's Cognitive Stage

\begin{tabular}{cccccc}
\hline CSt and MR & $27.392^{\mathrm{a}}$ & 4 & .657 & $.000<.05$ & High Assocition \\
CSt and SRL & $1.275^{\mathrm{a}}$ & 4 & .185 & $.866>.05$ & No Association \\
MR and SRL & $1.160^{\mathrm{a}}$ & 4 & .177 & $.885>.05$ & No Association \\
\hline
\end{tabular}

\section{CONCLUSION}

According to findings and discussion, the survey derived conclusion as follow. By employing TOLT, the survey found many students with 17, 45 years old had not reached formal stage, such as $19 \%$ students were at formal stage, $25 \%$ students were at transition stage, and $46 \%$ students were at concrete stage. In entirely, students obtained mathematical reasoning at very low grade level. While according to student's cognitive stage, formal students attained higher grade mathematical reasoning than the grades of transitional stage students, and concrete students and all MR grades were at very low grades level. Like that, either entirely or according to student's cognitive stage all students realized difficulties in all items of MR tasks.

Other conclussion were there was high association between cognitive stage and mathematical reasoning, but there were no association between cognitive stage and self regulated learning, and between mathematical reasoning and self regulated learnig. In general, findings of survey were sturdy with Inhelder and Piaget's of Child Cognitive Development, that in normal students formal stage will reach in 12 to 13 years old, or 13 to 14 years old, or in other cases in 19 to 20 years old, and formal students possessed higher abilities than transition students and concrete students on compiling any task which needed formal operational thinking. To determine cognitive stage of students according to Piaget's theory was not by biological age of students, but by student's abilities on completing logical reasoning tasks such as measured in TOLT (Sumarmo, 1987) or Longeot test (Sumarmo, 1987).

To enhance student's HOT of mathematical reasoning, it was suggested to strengthen student's mastering of mathematics prerequiste contents and processes and to familiarize students to solve non rutine and opened problems and to make students realize on rules and concepts which used in each step of enumeration. Further, to improve better students' self regulated learning, it was suggested: Perform teacher's behaviour as wish in SRL attitudes; accustomize students and teacher to behave as wish in SRL attitudes, and carry out integrated and continous mathematics teaching process.

\section{ACKNOWLEDGMENTS}

Thank you to the Headmaster of the SMK Ponpes Abu Manshur who gave permission to the researchers to be able to conduct research at the school. Thank you to Prof. Utari Sumarmo, M.Pd as a Lecturer in the Masters in Mathematics Education who has guided in conducting this research. Thank you to the parties who helped in conducting this research.

\section{REFERENCES}

Amalia, A., Syafitri, L. F., Sari, V. T. A., \& Rohaeti, E. E. (2018). Hubungan Antara Kemampuan Pemecahan Masalah Matematik Dengan Self Efficacy Dan Kemandirian Belajar Siswa SMP. Jurnal Pendidikan Matematika Inovatif, 1(5), 887-894.

Aminah, M., Kusumah, Y. ., Suryadi, D., \& Sumarmo, U. (2017). The Effect of 
Metacognitive Teaching and Mathematical Prior Knowledge on Mathematical Logical Thinking Ability and Self-Regulated Learning. International Journal of Instruction, 11(3).

Bernard, M., \& Rohaeti, E, E. (2016). Meningkatkan Kemampuan Penalaran dan Disposisi Matematik Siswa SMK dengan Pendekatan Kontekstual melalui Game Adobe Flash Cs 4.0. Edusentris: Jurnal Ilmu Pendidikan Dan Pengajaran, 3(1), 85-94.

Butler, D. L. (2002). Individualizing Instruction in Self-Regulated Learning. Http//Articles.Findarticles.Com/p/Articles/Mi_mOQM/Is_2_41/Ni_90190495.

Damayanti, D. ., Sumarmo, U., \& Maya, R. (2018). Improving Student's Mathematical Creative Thinking Ability and Self Regulated Learning using Sylver Approach. JPMI, 1(3), 268-278.

Dasari, D., \& Sumarmo, U. (2010). Improving Statistical Reasoning Ability of Students by Using PACE Model Approach. International Journal of Social and Humaniora. Alumni, 2, 21-39.

Djamarah, S. B., \& Zain, A. (2002). Strategi Belajar Mengajar. Jakarta: Rineka Cipta.

Hendriana, H., Rohaeti, E. E., \& Sumarmo, U. (2014). Hard Skill dan Soft Skill Mathematika. Bandung: Penerbit PT Refika Aditama.

Hendriana, H., \& Sumarmo, U. (2014). Penilaian Pembelajaran Matematika. Bandung: Penerbit PT Refika Aditama.

Kerlin, B. A. (1992). Cognitive Engagemant Style: Self-Regulated Learning and Cooperative Learning.

Koswara, U., Sumarmo, U., \& Kusumah, Y. . (2012). MeningkatkanKemampuan Komunikasi dan Penalaran Matematis Siswa SMA melalui Pendekatan Pembelajaran Kontekstual Berbantuan Program Autograph. Educationist: Jurnal Kajian Filosofi, Teori, Kualitas, Dan Manajemen Pendidikan, VI(2), 125-131.

Kusnandi, \& Sumarmo, U. (2010). Teaching Mathematics by using Abductive-Deductive Strategy for Improving Students'Proof Construction Ability. International Journal of Social and Humaniora, 2, 21-39.

L., C., \& Randi, J. (1999). Self-Regulated Learning. Http//Www.Personal.Psu.Edu/Users/h/ $x / H x k 223 /$ Self.Htm.

Maya, R., \& Sumarmo, U. (2014). Mathematical understanding and proving abilities: experiment with undergraduate student by using modified Moore learning approach. Journal on Mathematics Education 2, 2, 231-250.

Mulyana, A., \& Hendriana, H. (2015). Meningkatkan Kemampuan Penalaran Matematik dan Kemandirian Belajar Siswa SMPmelalui Pembelajaran Berbasis Masalah. Edusentris, Jurnal Ilmu Pendidikan Dan Pengajaran, 2.

National Council of Teachers of Mathematics. (2000). Principles and standards for school mathematics. Reston, VA: NCTM.

Offirston, T., \& and Sumarmo, U. (2012). Pendekatan Inkuiri Berbantuan Software Cinderella untuk Meningkatkan Kemampuan Penalaran danPemecahan Masalah Matematis Siswa MTs. Educationist: Jurnal Kajian Filosofi, Teori, Kualitas, Dan Manajemen Pendidikan, VI(2), 101-106.

Paris, \& Winograd. (1998). The National Science Foundation.

Permendikbud. Implementasi Kurikulum, 81 Menteri Pendidikan dan Kebudayaan Republik Indonesia $§(2013)$. 
Prasetio, D. A., Sumarmo, U., \& Sugandi, A. I. (2018). Improving Student's Mathematical Reasoning And Self Concept By Using Reciprocal Teaching. JPMI, 1(3), 283-294.

Qohar, A., \& Sumarmo, U. (2014). Improving Mathematical Communication Ability and Self Regulation Learning Of Yunior High Students by Using Reciprocal Teaching. Journalon Mathematics Education, 4(01), 59-74.

Retnaningsih, M., \& Sugandi, A. I. (2018). The Role of Problem Based Learning on Improving Students' Mathematical Critical Thinking Ability and Self-Regulated Learning. Innovative, 1(2), 60-69.

Rijaya, Sumarmo, U., \& Syaban, M. (2018). Improving Student's Mathematical Reasoning and Self Concept by Using Reciprocal Teaching. Journal of Innovative Mathematics Learning, 1(2), 86-94.

Rohaeti, E. E., Budiyanto, A. ., \& Sumarmo, U. (2014). Enhancing Mathematical Logical Thinking Ability and Self Regulated Learning of Students through Problem Based Learning. International Journal of Education, 8(1), 54-63.

Schunck, D. H., \& Zimmerman, B. J. (1998). No Title. Introduction to the Self Regulated Learning (SRL) Cycle.

Setiawati, E. (2014). Improving mathematical communication and reasoning ability and selfregulated learning of junior high school students through problem-based learning. Unpublished Doctoral Dissertation, Indonesia University of Education.

Sumarmo, U. (1987). Kemampuan Pemahaman dan Penalaran Matematika Siswa SMA dikaitkan dengan Kemampuan Penalaran Logik dan Beberapa Unsur Proses Belajar Mengajar. (Studi Deskriptif Analitik terhadap Siswa SMA Negeri dari Tujuh Kota). Unpublished Disertation at Post Graduate Study of Indonesia University of Education.

Sumarmo, U. (2006). Kemandirian belajar: Apa, mengapa dan bagaimana dikembangkan pada peserta didik.

Sumarmo, U., Hidayat, W., Zulkarnaen, R., \& Hamidah, Sariningsih, R. (2012). Kemampuan dan Disposisi Berpikir Logis, Kritis, Dan Kreatif Matematis: Eksperimen terhadap Siswa SMA Menggunakan Pembelajaran Berbasis Masalah dan Strategi Think-Talk-Write. Jurnal Pengajaran MIPA, 17(1), 17-33.

Sumarni, C., \& Sumarmo, U. (2017). Penalaran Matematik dan Kemandirian Belajar:Eksperimen terhadap Siswa SMP melalui Pembelajaran Generatif. Edusentris: Jurnal Ilmu Pendidikan Dan Pengajaran, 3(1), 290-299.

Wongsri, N., Cantwell, R. H., \& Archer, J. (2002). The Validation of Measures of SelfEfficacy, Motivation and self-Regulated Learning among Thai tertiary Students. The Annual Conference of the Australian Association for Research in Education.

Zumbrunn, S., Tadlock, J., \& Robert, E. D. (2011). Encouraging Self-Regulated Learning in the Classroom. A. Review of Literature. Sharon Virginia Commonwealth University. 